Ittishal Educational Research Journal July 2020, Vol. 1, No. 01, p. 82 - 90 http://journal.ittishal.net/index.php/ierj

DOI: 10.51425/ierj.v1i1.10

\title{
Learning to Read and Memorize the Qur'an as the Media to Help Make Easier the Students in Studying Arabic at Al-Azhar Cairo Islamic School of Palembang Indonesia
}

\author{
Achmad Brian Athoillah \\ Islamic School of Al-Azhar Cairo Palembang Indonesia \\ mas.achmadbrian@gmail.com
}

\begin{abstract}
Al-Azhar Islamic school Cairo Palembang is one of the school's curriculum of AlAzhar Cairo Egypt in the field of tahfidzul qur'an, Ulum Al-Syar'iyyah, and the Arabic language. The third matter that is all based on the Arabic that is good and right to support the achievement of a target that has been set by the school. Learn Quran is the basic foundation which was almost unknown even felt by every Muslim when still aged. Starting from pronouncing the letter per letter to understand it properly and correctly. Likewise in this school, also did not immediately leave the important teachings already planted by the teachers who have been teaching him. Not a few pupils from this school come from schools that barely taught again during the SD. As Christian schools or the like. It is clear to students the impact when they entered the Al-Azhar Islamic school Cairo. Starting from reading the Qur'an to other Islamic lessons. Especially the three materials were taken directly from Cairo Egypt writers already mentioned at the beginning. The impact is felt when taught their kids that are still far in the Arab pretty much felt by most faculty. And then learn the Qur'an was one of the influences for students who are native speakers. Why learn the Qur'an? Because according to save writers studying the Qur'an is the basic foundation then will be able to speak Arabic well. Or have a more precision level. As time went on in this school have started there though has not been so significant target achievements but it is demonstrating that that learning the Qur'an also has an impact on pupils in understanding Arab criticism. As for the
\end{abstract}


influence that can be pursued in a way getting used, provide understanding, invites them to participate actively in the reading or studying the Qur'an.

Keywords: Al-Qur'an; ulum Al-Syar'iyyah; Arabic; students. 


\section{INTRODUCTION}

Allah SWT said in the Holy Qur'an" Indeed, We have sent it down in the form of an Arabic Quran so that you understand it". From this verse, we will know that the Qur'an and the Arabic language have an inseparable connection. Because the Qur'an which is the orientation and guidance of human life has Allah revealed in the form of the Arabic language. The reason for the Qur'an to be revealed in Arabic is that the Arabic language at that time has reached qimmah (success). It has mature in terms of qawaidh, mufrodat, uslub (language style), and balaghah. Even so, the Arabic language used by the Qur'an is much higher than the Arabic that developed in the Arab society of that time. Experts of Arabic are surprised and amazed by the Arabic language used by the Qur'an. They cannot afford to match their beauty. This is one of the I'jaz (miracles) of the Qur'an in terms of its language. So Allah sends the Qur'an in Arabic not without reason. Allah knows that it is the best and mature when it is Arabic. ${ }^{1}$

Al-Qur'an is a factor that underlies the development of grammatical sciences in Arabic such as Sharaf, Nahwu, and Balaghah. This is because the Qur'an cannot be understood except in Arabic. ${ }^{2}$

As the language of the holy book of Islam, and also the language that is not only for the Arabian. But for all Muslims who want to study the Qur'an. It is not wrong if the Islamic scholar Ibn Taymiyyah said that the law of learning Arabic is wajib (Islamic law). Because the most important source of Islamic law is derived in Arabic and cannot be understood except only with this language. Until now the Qur'an is a standard reference for official Arabic languages throughout the world. ${ }^{3}$

According to Agus Tricahyo, there are at least two important factors that encourage the Companions of the Prophet to conduct Arabic studies, namely (1) Religious factors, as an effort to enable the Muslims to understand the Qur'an which is a good and true guide to their lives. (2) Factor of language, as an effort to 
anticipate the improper use of Arabic by the Arabian themselves or non-Arab Muslims. $^{4}$

Therefore, learning Arabic is part of religion. The law learns it is obligatory for Muslims who are able and responsible for the spread of Islam on the surface of the earth. Because it is impossible to understand the religion of Islam with the correct understanding but with Arabic. ${ }^{5}$

The above statement is similar to that said by Hasan, a doctoral commentary from Islamic Scientist University, Sudan that understanding Arabic before understanding the Qur'an is very important. It even becomes a conditional requirement for someone who wants to understand the Qur'an to master the Arabic language first. A person named Mujahid once said, "It is not lawful for a person who believes in Allah and the latter speaks of something contained in the Qur'an while he does not understand Arabic". This means that the law is illegal for someone who does not speak Arabic well but dares to argue about something in the Qur'an. ${ }^{6}$

This paper is made to know that studying and memorizing the Qur'an can help students to more easily learn Arabic in the Al-Azhar Islamic school environment of Cairo Palembang.

\section{DISCUSSION AND THE RESULT}

\section{Student Recitation Growth}

There are 12 teachers of the Quran in Al-Azhar Islamic Junior High School in Cairo this Palembang. They are the day to guide students in studying the Qur'an both in reading and memorizing. In this school, especially SMP there are 3 grades or classes. Grades 7, 8, and 9. Those grades that use the Cairo curriculum are grade 7 in the last school year. It has been one year since the school implemented the Cairo AlAzhar curriculum in Egypt.

The impact is felt when taught their kids that are still far in the Arab pretty much felt by most faculty. And then learn the Qur'an was one of the influences for

\footnotetext{
${ }^{4}$ Agus Tricahyo, Pengantar Linguistik Arab, (Ponorogo: STAIN Ponorogo Press, 2011), page.96.

${ }^{5}$ Ainur Rofiq bin Ghufron, Ringkasan Kidah-kaidah Bahasa Arab, (Gresik: Pustaka AlFurqon, 2011), page.iii.

${ }^{6}$ Hasan, Op.cit.,
} 
pupils who are native speakers. Why learn the Qur'an? Because according to save writers studying the Qur'an is the basic foundation then will be able to speak Arabic well. Or have a more precision level.

For the teachers, there are some obstacles that once the author asks them. Some of the following are as follows:

\section{(1) Doesn't understand hijaiyah abjad well yet}

From the students in this school, it was not only those who were good at studying to be accepted at this school. But those who may not have been able to study the Koran but if there is an ability or advantage in other fields are also accepted. There are several students from non-Muslim elementary schools. They are all students who get special attention from Al-Qur'an instructors. Because indeed they have very little to learn about Islam, including the Qur'an.

(2) Doesn't balance between adding new memorization and muroja'ah in managing time yet

For students who have already memorized at school, we as teachers continue to remind students to continue muroja'ah. This is still the case with some students who have not been able to do memorized repetition accompanied by adding memorization.

\section{(3) The Students still feel shocked by memorizing}

In Cairo, the curriculum for junior high school at the start of from Huud to Nisa. And the Surah was his long verses to their memorized.

\section{Methods in memorizing}

There are several methods that schools use to help students read and memorize well:

(1) Talaqqi method

This is a way the school uses to guide students so that they can read al-Quran well. From here they can know how to properly affirm the Qur'anic verses properly and correctly.

(2) Tashif method

After being taught by the teacher, the students then see the Qur'anic texts to know how the verse should be read. 
(3) Tasmi' method

At the end of the lesson, they are required to deposit memorization. With the hope that they can remember what they read and whether it is by good and true reading. These three methods are used by schools to improve their ability to read and memorize the Qur'an.

\section{Result}

In the years 2017-2018, the Cairo curriculum is used. 1 year, the Quran teacher also teaches about reading and memorizing the Qur'an. Here is the achievement of students in memorizing the Qur'an7:

\begin{tabular}{|c|c|c|c|}
\hline Grade/ class & $\begin{array}{l}\text { The sum of } \\
\text { students }\end{array}$ & The Reached & $\begin{array}{c}\text { Doesn't } \\
\text { Reached yet }\end{array}$ \\
\hline 7 Khalid bin Walid & 27 & $75 \%$ & $25 \%$ \\
\hline 7 Sa'ad bin Waqqash $^{\prime}$ & 26 & $70 \%$ & $30 \%$ \\
\hline 7 Thariq bin ziyad & 26 & $80 \%$ & $20 \%$ \\
\hline 7 Amru bin Ziyad & 26 & $90 \%$ & $10 \%$ \\
\hline 7 Zaid bin Haritsah & 26 & $70 \%$ & $30 \%$ \\
\hline 8 Imam Hambali & 28 & $70 \%$ & $30 \%$ \\
\hline 8 Imam Hanafi & 27 & $80 \%$ & $20 \%$ \\
\hline 8 Imam Maliki & 27 & $70 \%$ & $30 \%$ \\
\hline 8 Imam Syafi'ie & 27 & $70 \%$ & $30 \%$ \\
\hline 9 Salim Al-Bishri & 27 & $80 \%$ & $20 \%$ \\
\hline 9 Hasan Al Quwaisiny & 26 & $75 \%$ & $25 \%$ \\
\hline $\begin{array}{l}\text { 9Musthofa } \\
\text { Maraghi }\end{array}$ & 27 & $85 \%$ & $15 \%$ \\
\hline $\begin{array}{ll}\text { 9Abdul } & \text { Halim } \\
\text { Mahmud } & \end{array}$ & 26 & $80 \%$ & $20 \%$ \\
\hline
\end{tabular}

${ }^{7}$ Data on the development of memorization of Al-Azhar Islamic Junior High School students of Palembang in Academic Year: 2017-2018. 
From these data, students who have not completed the target are expected to increase the hours of Al-Qur'an learning in their homes by bringing in teachers from outside or private.

Students at this school gradually understood in hijaiyah letters that it was also used in Arabic.

As time went on at this school, there were already results, even though the achievement target was not so significant, but it showed that learning the Qur'an also influenced students in understanding Arabic. The influence can be pursued by getting used to, providing understanding, inviting them to participate actively in reading or studying the Qur'an. These ways schools do with a variety of activities such as prayer and dzikr congregation, extracurricular Arabic, initiating learning and every activity in Arabic.

In the end, learning to memorize and read the Qur'an can help students to understand the Arabic language in this school. The curriculum of Cairo that is applied can also support smooth learning of Arabic. From data, developments are already memorized many students can read and memorize Qur'an well that later can help students learn and understand Arabic.

\section{CONCLUSION}

In learning activities to read and memorize Al-Qur'an, there is a very close relationship that can help students understand Arabic lessons. That can be done by students to be able to speak and listen to Arabic. Our foundation learned before learning Arabic is to understand hijaiyah letters and connect them. And it was obtained when they learned to read and memorize the Qur'an in this school. As well as holding supporting activities that can help students understand Arabic. Such as prayers and dhikr congregation, Arabic extracurricular, initiating learning, and every activity in Arabic.

Learn Quran is the basic foundation which was almost unknown even felt by every Muslim when still aged. Starting from pronouncing the letter per letter to understand it properly and correctly. Likewise in this school, also did not immediately leave the important teachings already planted by the teachers who have 
been teaching him. Not a few pupils from this school come from schools that barely taught again during elementary school. As Christian schools or the like. It is clear to students the impact when they entered the Al-Azhar Islamic school Cairo. Starting from reading the Qur'an to other Islamic lessons. Especially for the three materials taken directly from Cairo Egypt that the writers already mentioned at the beginning.

In the Qur'anic material in this school, it is taught to begin with the Tajwid knowledge, connect the letters well and true until they memorize the Qur'an. Because indeed the curriculum is taken from Cairo, it is required for each student to memorize the Qur'an. Memorization process applied by schools ranging from Talaqqi, Tashif, and Tasmi '. These three methods are applied to help them to memorize well and correct. From here their development is known in memorizing the Qur'an.

The three methods applied by the school are the means of introducing Arabic to students to then read the Arabic letters so they can understand it well. And it can also explain by giving understanding by paragraph or translations to be more convincing of the students of this Qur'an.

From here, students will learn how to read Arabic scripts and learn more about the meaning of the verse or words in the Qur'an. 


\section{REFERENCES}

Administrative data of the Al-Azhar Islamic Middle School in Cairo Palembang Indonesia. Retrieved September 2016.

Aflisia, N. (2016). Urgensi bahasa Arab bagi hafizh Al-Qur'an. FOKUS Jurnal Kajian Keislaman dan Kemasyarakatan, Volume 1, Nomor 1.

Al-Qur'an dan terjemahannya (Transliteration Edition). (2015). Kementerian Agama Republik Indonesia. PT. Tiga Serangkai.

Hasan, Moh Abdul Kholiq. Memahami Al-Qur'an. Mutlak Paham Bahasa Arab. Berita Akbar, retrieved October 8, 2013.

Rofiq, A. (2011). Ringkasan kaidah-kaidah bahasa Arab. Gresik: Pustaka Al-Furqon. Tricahyono, A. (2011). Pengantar linguistik. Ponorogo: STAIN Ponorogo Press. 